\title{
PERENCANAAN KEPERAWATAN PADA PASIEN DI INSTALASI GAWAT DARURAT (IGD) RUMAH SAKIT
}

TATI OKTIANA TAMBA

\author{
tatitamba26@gmail.com
}

\section{LATAR BELAKANG}

Keperawatan adalah suatu bentuk pelayanan profesional yang merupakan bagian integral dari pelayanan kesehatan berdasarkan ilmu. Tenaga keperawatan adalah salah satu tenaga kesehatan yang juga ikut dalam melaksanakan penanganan terhadap pasien. Tenaga keperawatan merupakan The caring profession yang memiliki peranan penting dalam menghasilkan kualitas pelayanan kesehatan di rumah sakit. Pelayanan yang diberikan berdasarkan pendekatan bio-psiko-sosialspiritual yang dilaksanakan selama 24 jam dan berkesinambungan merupakan kelebihan tersendiri dibandingkan pelayanan yang lainnya. Perencanaan Keperawatan merupakan suatu proses didalam pemecahan masalah yang dimana keputusan awal tentang sesuatu apa yang akan dilakukan,bagaimana dilakukan,siapa yang melakukan dari semua tindakan keperawatan.

Sebagai bagian integral pelayanan kegawatdaruratan, pelayanan keperawatan mengutamakan akses pelayanan kesehatan bagi pasien dengan tujuan untuk mencegah dan mengurangi angka kesakitan, kematian dan kecacatan. Kemampuan perawat sebagai pelaksana pelayanan keperawatan gawat darurat masih sangat terbatas untuk mendukung terwujudnya pelayanan kegawatdaruratan yang berkualitas.Saat bekerja di rumah sakit, perawat diharapkan mampu melakukan triase, resusitasi dengan atau tanpa alat, mengetahui prinsip stabilisasi dan terapi definitif, mampu bekerja dalam tim, melakukan komunikasi dengan tim, pasien beserta keluarganya.

Perawat di Instalasi Gawat Darurat Rumah Sakit tentu memegang peran penting karena Instalasi Gawat Darurat merupakan pintu gerbang rumah sakit yang berfungsi dalam memberikan perawatan awal pada setiap pasien. Perawat menjadi profesi dengan jumlah terbanyak dalam sistem kesehatan dan keberadaannya penting sebagai first responder (Johnstone \& Turale, 2011). Kegiatan keperawatan banyak diperlukan termasuk pencegahan, kesiapsiagaan, respon, pemulihan, dan rekonstruksi atau rehabilitasi. Kesiapan merupakan hal yang krusial, termasuk kesiapan tenaga perawat sebagai first responder bencana dalam fase tanggap darurat (Wijaya, Andarini, \& Setyoadi, 2015). Sementara dalam pelaksanaannya, perawat tidak maksimal dalam melakukan implementasi. Hal ini diperkuat dengan penelitian Fung (2008) yang menyatakan bahwa 97\% perawat tidak mempunyai persiapan yang baik dalam penanganan bencana. 
Respon dini sangat diperlukan untuk menyelamatkan nyawa sebanyak mungkin, memberikan perawatan untuk memenuhi kebutuhan yang mendesak dan mengurangi dampak kesehatan jangka panjang dari bencana (Chapman \& Arbon,2008).

Instalasi Gawat Darurat memiliki pelayanan dasar yang wajib dilakukan oleh petugas kesehatan untuk meningkatkan kualitas pelayanan yang meliputi keamanan, efektivitas, berpusat pada pasien, ketepatan waktu dalam melakukan tindakan, efisiensi dan keadilan (Sørup, Jacobsen dan Forberg,

2013).Permasalahan pelayanan kesehatan secara umum adalah belum merata dan dirasakan pelayanan kesehatan oleh seluruh lapisan masyarakat, pelayanan masih terfokus pada pengembangan puskesmas dan rumah sakit terutama pada upaya preventif dan pelayanan belum mengacu dalam satu sistem.

Instalasi Gawat Darurat (IGD) Rumah Sakit memiliki peran utama dalam penanggulangan gawat darurat untuk melakukan triase, resusitasi dan stabilisasi.(2) Masih adanya perbedaan pengertian gawat darurat antara masyarakat awam dengan petugas kesehatan menyebabkan lonjakan angka kunjungan ke pelayanan gawat darurat. Berdasarkan data Direktorat Jenderal Bina Pelayanan Medik Depkes, pada tahun 2007 jumlah rumah sakit di Indonesia sebanyak 1.319 yang terdiri atas 1.033 RSU dengan jumlah kunjungan ke RSU sebanyak 33.094.000, sementara data kunjungan ke IGD sebanyak 4.402.205 (13,3\% dari total seluruh kunjungan di RSU), dari jumlah seluruh kunjungan IGD terdapat 12,0 \% berasal dari pasien rujukan.(3) Data Kunjungan Pasien di RSUD dr. R. Soetijono Blora menunjukkan bahwa jumlah kunjungan di IGD sebanyak 11.335 (11,36\%) dari total seluruh kunjungan rumah sakit sebanyak 48.056 pada tahun 2016 dan dalam tiga tahun terakhir mengalami kenaikan jumlah kunjungan.(4) Sedangkan SPM IGD di RSUD Dr. R. Soetijono Blora berdasarkan Peraturan Bupati No. 5 Tahun 2010, hanya mengadopsi empat indikator saja dari delapan indikator yang tercantum di Kepmenkes No. 129 Tahun 2008, yaitu kemampuan menangani life saving 100\%, waktu tanggap pelayanan dokter $\leq 5$ menit, kematian pasien $\leq$ 0,5\%, dan pemberi pelayanan gawat darurat yang bersertifikat BLS / PPGD / GELS / ALS yang masih berlaku 100\%.(5)(6) Hal ini berarti dari awal perencanaan dalam perumusan SPM IGD sudah tidak sesuai dengan Kepmenkes yang berdampak pada capaian per indikator yang belum terpenuhi.

Permasalahan pelayanan kesehatan secara umum adalah belum merata dan dirasakan pelayanan kesehatan oleh seluruh lapisan masyarakat, pelayanan masih terfokus pada pengembangan puskesmas dan rumah sakit terutama pada upaya preventif dan pelayanan belum mengacu dalam satu sistem.

\section{METODE}

Pencarian artikel jurnal tentang pelaksanaan keperawatan pada pasien di Instalasi Gawat Darurat melalui internet atau google. Kemudian dilakukan pemeriksaan berdasarkan kelayakan dan kriteria yang 
ditentukan: (1) Teks lengkap, (2) Terbit 10 tahun terakhir, (3) Artikel penelitian asli. Artikel Jurnal yang tidak masuk dalam kriteria kelayakan karena hanya berupa sebatas surat ke editor, berbahasa selain Indonesia dan Inggris, dan tidak sesuai dengan struktur penulisan pada umumnya. Setelah dilakukan kelayakan kriteria artikel jurnal didapat beberapa jurnal berdasarkan kelayakan untuk dilanjutkan dalam tinjauan kritis. Pengkajian tinjauan kritis berdasarkan hasil yang diperoleh adalah sebanyak 10 artikel penelitian yang relevan untuk dijadikan sebagai bahan tinjauan literatur.Setelah itu,penulis dalam kajian ini membandingkan kajian pustaka dan beberapa jurnal yang ada serta melakukan analisis dengan data sekunder yaitu kajian pustaka terhadap beberapa referensi yang mendukung kajian ini . Beberapa referensi dikutip dan dikaji kemudian di buat analisisnya.

\section{HASIL}

Suatu proses karena melalui komunikasi seseorang menyampaikan dan mendapatkan respon. Bagi perawat yang bekerja di IGD keterampilan ini adalah sebuah keterampilan mutlak yang harus dimiliki, karena dengan komunikasi seorang perawat dapat melaksanakan keperawatan secara profesional dalam mengimplementasikannya. karna dengan begitu perawat dapat mengumpulkan data pengkajian, mengumpulkan data fokus untuk menegakkan diagnosa keperawatan serta dengan komunikasi akan memperlancar semua tindakan keperawatan yang direncanakan sampai ke proses pemberian pendidikan kesehatan pada pasien.

Ringkasan Pelayanan Keperawatan pada Pasien Lansia di Instalasi Gawat Darurat 1.Taylor, Rush danRobinson,(2015)

Tujuan : Mengeksplorasi berbagai pengalaman perawat dalam perawatan di IGD.

Desain : Studi etnografi

Sampel : Wawancara sebanyak 7 perawat

Temuan :Pengalaman pelayanan perawat kepada pasien menemukan 3 konten utama yang penting diperhatikan yaitu budaya, ketidaksesuain pelayanan IGD dengan pasien, ketidakcocokan dalam pengelolaan.

2.Morphet dkk., (2015)

Tujuan : Menyelidiki pengalaman keluarga yang memiliki anggota keluarga di fasilitas perawatan pasien yang akan dipindahkan ke IGD. 


\section{Desain : Deskriptif kualitatif}

Sampel : Wawancara 24 anggota keluarga

Temuan: Keluarga yang menemani lansia di IGD memiliki kebutuhan yang meliputi kejelasan komunikasi antara perawat dan keluarga, penjelasan tentang peran yang melibatkan keluarga di IGD, komunikasi tentang persepsi perawatan kesehatan, dan kemampuan perawat dalam memberikan perawatan khusus.

3 Boltz dkk., (2013)

Tujuan : Menggambarkan pelayanan perawat untuk meningkatkan pelayanan di IGD

Desain : Analisis kualitatif

Sampel : Eksplorasi tanggapan perawat yang berjumlah 527 perawat

Temuan : Lima aspek penting bagi perawat dalam melakukan perawatan pasien di IGD meliputi rasa hormat kepada pasien dan keluarga yang menemani, penerapan prosedur pelayanan keperawatan yang tepat, waktu dan staf untuk tindakan yang benar,trnsisi,dan lingkungan yang aman.

4 Lennox dkk., (2019)

Tujuan :Mengeksplorasi perawat tentang perawatan pasien lansia di IGD

Desain : Kualitatif eksplorasi

Sampel : Wawancara berjumlah 54 perawat

Temuan : Kebutuhan lansia dapat dipahami perawat dengan cara menyesuaikan pendekatan komunikasi dengan cara seperti menaikan volume suara, memperlambat berbicara. Masalah lain yang ditemukakn adalah ketidaksesuaian kebutuhan peralatan IGD dan keterbatasan waktu dalam perawatan transisi di IGD.

5 Nascimento dkk.,(2015)

Tujuan : Pandangan para profesional keperawatan untuk memahami lingkungan Instalasi Gawat Darurat dalam perawatan lansia

Desain : Eksploratif dan deskriptif kualitatif

Sampel : Wawancara terstruktur sebanyak 15 profesional keperawatan 
Temuan : Kebutuhan pasien lansia selama proses perawatan di Instalasi Gawat Darurat tidak terpenuhi, hal ini dikaitkan dengaan ketidaksesuaian peralatan dan lingkungan dengan kebutuhan permintaan perawatan pasien seperti kenyamanan, privasi pasien, perawatan integritas kulit.

6 Mira, Marja danPaivi, (2016)

Tujuan : Menyelidiki keterlibatan keluarga yang diberikan pendidikan pemulangan Gawat Darurat pasien .

Desain : Deskriptif kualitatif

Sampel : Wawancara tematis kepada 15 perawat, 5 anggota keluarga, dan 7 pasien

Temuan : Perawat meyakini bahwa partisipasi keluarga dalam mengikuti pendidikan kepulangan pasien dibagi menjadi 4 karakter keluarga yang meliputi pengakuan keluarga, keluarga dikucilkan, keluarga merupakan sumber bagi perawat, dan sebagai inisiator.

7 Rawson dkk., (2017)

Tujuan : Mengidentifikasi pengetahuan dan penilaian diri perawat IGD

Desain : Cross-sectional

Sampel : Pemberian kuesioner kepada 250 perawat di Instalasi Gawat Darurat

Temuan : Pengetahuan dan penilaian diri perawat yang memenuhi kebutuhan biologis, psikologis, fisiologis, dan sosial pada lansia di IGD memiliki perbedaan

\section{PEMBAHASAN}

Gambaran masyarakat Indonesia di masa depan yang ingin dicapai melalui pembangunan kesehatan adalah masyarakat, bangsa dan negara yang ditandai oleh penduduk yang hidup dalam lingkungan dan dengan perilaku hidup sehat, memiliki kemampuan untuk menjangkau pelayanan kesehatan yang bermutu secara adil dan merata, serta memiliki derajat kesehatan yang setinggi-tingginya diseluruh wilayah Republik Indonesia. Gambaran keadaan masyarakat Indonesia dimasa depan atau visi yang ingin dicapai melalui pembangunan kesehatan tersebut dirumuskan sebagai Indonesia Sehat 2010 (Depkes RI, 2008). Untuk dapat mewujudkan visi Indonesia Sehat 2010, ditetapkan empat misi pembangunan kesehatan meliputi menggerakkan pembangunan nasional berwawasan kesehatan, mendorong kemandirian masyarakat untuk 
hidup sehat, memelihara dan meningkatkan pelayanan kesehatan yang bermutu, merata dan terjangkau serta memelihara dan meningkatkan kesehatan individu, keluarga dan masyarakat beserta lingkungannya (Depkes RI, 2008).

Dalam pelaksanaan asuhan keperawatan kepada pasien -tidak ditemukan kendala/hambatan yang ditetapkan dalam intervensi secara teoritis dapat dilaksanakan di lahan praktek. Perubahan persepsi sensori b/d ketidakseimbangan glukosa/insulin dan atau elektrolit. Diagnosa ini tidak diangkat pada kasus karena pada pengkajian pasien tidak ditemukan adanya tanda-tanda perubahan persepsi sensori, seperti penurunan tingkat kesadaran, Waktu dikaji pasien tampak tenang. Ketidakberdayaan b/d penyakit jangka panjang/ progresif yang dapat diobati dan ketergantungan pada orang lain. Diagnosa ini tidak diangkat pada kasus karena pasien tidak menunjukkan adanya tandatanda ketidakberdayaan, pasien nampak tegar dan berusaha untuk sembuh dari penyakitnya. Kurang pengetahuan tentang penyakit, prognologis dan kebutuhan pengobatan berhubungan dengankurangnya pemajanan / mengingat, kesalahan interpretasi informasi.

Layanan keperawatan di Instalasi Gawat Darurat menyadari situasi saat kunjungan dan menerima layanan perawatan memiliki permintaan kebutuhan biologis, fisiologis, psikologis dan sosial, kemampuan perawat sebagai pemberi layanan darurat membutuhkan kesadaran akan pengetahuan perawatan pada pasien .Perhatian khusus yang diberikan kepada di Instalasi Gawat Darurat terdiri dari 4 konten untuk pemenuhan pelayanan keperawatan sebagai berikut:

Budaya dan Lingkungan

Instalasi Gawat Darurat merupakan perawatan yang cepat dan tepat, sehingga model ini tidak konsisten dengan perawatan untuk memenuhi kebutuhan biologis, psikologis, sosial seperti memberikan perawatan nyeri, kebersihan diri, dan pemeliharaan kemandirian pasien (Deasey, Kable dan Jeong, 2016). Pelayanan perawat dalam memberikan perawatan kepada dianggap merupakan sebuah tantangan karena kompleksitas kebutuhan perawatan pasien dan keterbatasan waktu selama proses perencanaan perawatan di IGD.

\section{Komunikasi}

Komunikasi antara perawat, pasien, dan keluarga dibutukan untuk kejelasan selama proses perawatan seperti menaikan volume suara dan mengurangi kecepatan berbicara, memberikan advokasi kepada keluarga dengan maksud untuk meningkatkan pemahaman keluarga selama proses perawatan di IGD. Asuhan keperawatan merupakan proses terapeutik yang melibatkan hubungan kerjasama antara perawat dengan klien dan keluarga, untuk mencapai tingkat kesehatan yang optimal dalam melakukan proses 
terapeutik maka perawat melakukan metode ilmiah yaitu proses keperawatan (Tjokronegoro Artjatmo, 2009). Proses keperawatan merupakan tindakan yang berurutan dilakukan secara sistematis dengan latar belakang pengetahuankomprehensif untuk mengkaji status kesehatan klien, mengidentifikasi masalah dan diagnosa, merencanakan intervensi, mengimplementasikan rencana dan mengevaluasi rencana sehubungan dengan proses keperawatan pada klien dengan gangguan sistem endokrin dan Metabolik (Brunner dan Suddart, 2007).

Transisi

Perawatan transisi membutuhkan koordinasi dan memperhatikan kualitas pelayanan keperawatan selama perpindahan antara sesama penyedia pelayanan keperawatan pasien. Perbaikan pelayanan perawatan transisi IGD adalah indenfikasi faktor terkait yang meliputi: (1) Keluarga terdekat (advokasi, dukungan, dan perantara informasi), (2) Karakteristik pasien (tingkat kepuasan, tingkat keamanan, kondisi klinis), (3) Kompetensi tenaga kesehatan(profesional, sistem, kolaboratif, (4) Pertukaran informasi (lisan, tertulis, dan elektronik), dan (5) Konteks (stabilitas, variabilitas, insentif perubahan, jumlah serah terima pasien) (Storm dkk., 2014).

\section{Keterlibatan keluarga}

Dalam proses pelayanan keperawatan selama di IGD, keluarga memiliki peran dalam menjalani perawatan seperti berperan sebagai pengawas status kesehatan, pembuat keputusan dan mendampingi pasien selama perawatan (Reis, Sena dan Menezes, 2016; Nogueira dkk., 2016). Perawat yang melibatkan keluarga untuk mengikuti pendidikan kepulangan pasien yang berpengaruh terhadap peningkatan kepercayaan diri dalam penanganan perawatan selama di rumah pasien. Inisiatif keluarga sebagai pendukung dalam proses perawatan selama di IGD diperlukan seperti pendampingan pasien, dan keperluan obat-obatan yang sebelumnya digunakan untuk perawatan lanjut dan kajian oleh perawatan (Nikki, Lepisto danPaavilainen, 2012).

Dalam pelaksanaan asuhan keperawatan kepada pasien -tidak ditemukan kendala/hambatan yang ditetapkan dalam intervensi secara teoritis dapat dilaksanakan di lahan praktek. Perubahan persepsi sensori b/d ketidakseimbangan glukosa/insulin dan atau elektrolit. Diagnosa ini tidak diangkat pada kasus karena pada pengkajian pasien tidak ditemukan adanya tanda-tanda perubahan persepsi sensori, seperti penurunan tingkat kesadaran, Waktu dikaji pasien tampak tenang. Ketidakberdayaan b/d penyakit jangka panjang/ progresif yang dapat diobati dan ketergantungan pada orang lain

Diagnosa ini tidak diangkat pada kasus karena pasien tidak menunjukkan adanya tandatanda ketidakberdayaan, pasien nampak tegar dan berusaha untuk sembuh dari penyakitnya. Kurang pengetahuan 
tentang penyakit, prognologis dan kebutuhan pengobatan berhubungan dengankurangnya pemajanan / mengingat, kesalahan interpretasi informasi.

\section{PENUTUP}

Dalam Perencana keperawatan yang dikemukakan dalam kasus sesuai dengan kebutuhan klien, sedangkan perencanaan keperawatan dalam teori tetap memperhatikan kondisi dan respon klien. Implementasi asuhan keperawatan mengacu pada masalah keperawatan yang muncul dengan berpedoman pada teori dan tetap memperhatikan keadaan klien, respon klien serta fasilitas yang ada dan kebijakan dari rumah sakit. Pada evaluasi keperawatan, diagnosa keperawatan yang muncul ada tiga. Dari ketiga diagnosa keperawatan tersebut ada satu diagnosa keperawatan yang belum teratasi.Layanan keperawatan di Instalasi Gawat Darurat berkaitan dengan kebutuhan biopsikososial. Selama pelayanan keperawatan, terdapat poin penting yang ditemukan seperti budaya dan lingkungan IGD, transisi, komunikasi dan keterlibatan keluarga. Hal ini menjadi dasar untuk meningkatkan kualitas pelayanan keperawatan pada pasien selama perawatan di IGD.

\section{DAFTAR PUSTAKA}

Amad Mochamad,Septo Pawelas Arso,Yuliani Sefyaningsih.(Oktober 2019).Implementasi Sistem Penanggulangan gawat darurat terpadu K119 (SPGDT) Di Kabupaten Kudus.Jurnal Keperawatan dan Kesehatan Masyarakat"Cendeki Utama".Vol 8.No 2.

Butar-Butar, J., \& Simamora, R. H. (2016). Hubungan Mutu Pelayanan Keperawatan dengan Tingkat Kepuasan Pasien Rawat Inap di RSUD Pandan Kabupaten Tapanuli Tengah. Jurnal Ners Indonesia, 6(1), 50-63.

Denny Susanto. (Desember 2019). Pelayanan keperawatan Pada Pasien Lansia Saat Kunjungan dan Menerima Perawatan Di Instalasi Gawat Darurat.Dinamika Kesehatan Jurnal Kebidanan dan Keperawatan. vol 10. No 2

Diah Ayu ,Ayu prawesti,Valentina.(Desember 2017). Kesiapan Perawat Gawat Darurat Rumah Sakit Umum Daerah Kabupaten Bandung dalam Menghadapi Bencana Jurnal Keperawatan 'Aisyiyah'.Vol 4.No 2

Erlan Nurmansyah, F. Sri Susilaningsih, Setiawan.(Desember 2014).Tingkat Ketergantungan dan Lama Perawatan Pasien Rawat Observasi di IGD.RS Sekarwangi, Fakultas Keperawatan Universitas Padjadjaran.Vol 2 .No 3

Fajrillah,Nurfitriani.(Januari 2016).Hubungan stress kerja dengan kinerja perawat pelaksanaan dalam melaksanakan pelayanan keperawatan di instalasi Gawat Darurat Rumah Sakit Umum Anutapura Palu.Jurnal Keperawatan Sriwijaya.Vol 3.No 2.

Heru Suwardianto,Vitaria Wahyu Astuti.(2020).Buku Ajar Keperawatan Kritis : Pendekatan Evidenci Base Practice Nursing.Chakra Brahmanda Lentera. 
MALANG(Phenomenology: caring of nurse for clients with critical conditions at emergency installation-dr. Saiful Anwar Hospital).Jurnal IImu Kesehatan . Vol.2 No. 1

Muhammad Purnomo. 2016. Pencapaian Standar Pelayanan Gawat Darurat di Rumah Sakit Umum Habibullah Berdasarkan Standar Pelayanan Minimal Rumah Sakit Tahun 2014.Stikes Muhammadiyah Kudus.

Simamora, R. H. (2005). Hubungan Persepsi Perawat Pelaksana Terhadap Penerapan Fungsi Pengorganisasian Yang Dilakukan Oleh Kepala Ruangan Dengan Kinerjanya Diruang Rawat Inap RSUD Koja Jakarta Utara (Doctoral dissertation, Tesis FIK UI, Tidak dipublikasikan).

Sri Widi Astuti,Septo Welas Arso,Eka Yunila Fatmasari. (Oktober 2017). Analisis Proses Perencanaan dan Evaluasi Pelaksanaan Standar Pelayanan Minimal Instalasi Gawat Darurat di RSUD (Dr R. Soetijono Blora). Jurnal Kesehatan Masyarakat. Vol 5. No 4

Yulia Candra Lestari. (Oktober 2019) .Identifikasi Upaya Peningkatan Kualitas Pelayanan Keperawatan Gawat Darurat di IGD Perspektif Perawat. Jurnal Keperawatan Florence. vol 4.No 1 